\title{
Camel Milk: An Important Natural Adjuvant
}

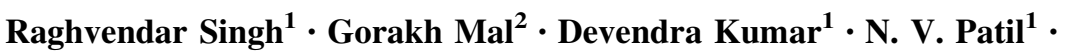 \\ K. M. L. Pathak ${ }^{3}$
}

Received: 31 January 2017/Accepted: 21 August 2017/Published online: 21 September 2017

(C) The Author(s) 2017. This article is an open access publication

\begin{abstract}
One humped camel (Camelus dromedarius) breeds, indigenous to India, have been shown to have good genetic potential to produce milk. Camel milk not only is cost-effective in terms of feed conversion but also has additional advantage of longer lactation period and unique adaptation mechanisms for warm arid and semiarid regions. The key features of camel milk in comparison with other milk are low fat with high content of unsaturated and long-chain fatty acid. The proteins are rich in lactoferrin and lysozymes, but deficient in $\beta$-lactoglobulin. It has higher percentage of total salts, free calcium, protective proteins and vitamin C, and some of the microminerals, viz iron, copper and zinc. Physicochemical properties of camel milk are also unique and useful for food processing. The shelf life of raw camel milk is $8-9 \mathrm{~h}$, which can be extended up to $18-20 \mathrm{~h}$ through activation of camel lactoperoxidase system. Heat stability of camel milk is shown to be highest at $\mathrm{pH} 6.8$, and it ferments relatively slowly compared to the cattle milk. The camel milk is successfully processed for producing a variety of products, such as fermented milk ('lassi'), soft cheese, flavored milk and 'kulfee' (a kind of ice cream). Camel milk has been traditionally used in different regions of the world as natural adjuvant for managing a variety of human diseases.
\end{abstract}

Keywords Camel milk · Proteins · Lactose intolerance $\cdot \beta$-Lactoglobulin · Insulin · Medicinal properties ·

Bioactive peptides $\cdot$ Nutraceuticals $\cdot$ Shelf life

\section{Introduction}

The global camel population, spread across 47 countries, is estimated to be around 26.99 million. About 83 percent of the camel population inhabits mainly the Eastern and Northern Africa and the rest are present in the Indian subcontinent and Middle East. Somalia has the highest population of 7.10 million. India stands tenth in the world with 0.38 million camels [33]. In last five decades, the world's

Raghvendar Singh

raghvendar@gmail.com

1 National Research Centre on Camel, P. B. No. 07, Bikaner, Rajasthan, India

2 Indian Veterinary Research Institute, Regional Station, Palampur, H.P., India

3 DUVASU, Mathura, U.P., India camel population increased by about twofold as a result of nearly threefold increase in the Africa region, while it recorded a decreasing trend in the Asian region including India (Table 1). This might be due to declining trend in the use of camel in agricultural and transport works and less demand of camel milk and other products in these countries. One important reason of increasing camel population in African region is the demand of camel milk and meat.

In India, camels are mainly confined to the States of Rajasthan (81.4\%), Gujarat (7.6\%), Haryana (4.7\%), Bihar (2.2\%) and Uttar Pradesh (2.0\%) [19]. Major reduction in the camel population has been during the last two decades when it reduced from 0.9 to 0.4 million (Table 2). The main reasons for the continuous decline in camel population in India are significant reduction in the traditional use of camels for draft purpose, transport of goods, use in agricultural operation and the shrinkage of rangelands. Other causes for decline in the camel population are the 
Table 1 Periodical change in camel population of major regions of the world (1961-2013)

\begin{tabular}{llll}
\hline Year & \multicolumn{3}{l}{ Camel population (Million) } \\
\cline { 2 - 4 } & World & Africa region & Asia region (India) \\
\hline 1961 & 12.93 & 8.63 & $4.02(0.9)$ \\
1971 & 16.82 & 12.41 & $4.17(1.1)$ \\
1981 & 18.41 & 14.00 & $4.17(1.08)$ \\
1991 & 19.32 & 14.73 & $4.33(1.03)$ \\
2001 & 20.78 & 17.11 & $3.66(0.63)$ \\
2013 & 26.99 & 23.00 & $3.98(0.4)$ \\
\hline
\end{tabular}

Source FAOSTAT (2015) [33]

Table 2 Percent change in Indian camel population (1961-2012)

\begin{tabular}{lll}
\hline Year & Population (Million) & Percent change \\
\hline 1961 & 0.90 & - \\
1966 & 1.00 & $(+) 11.11$ \\
1972 & 1.10 & $(+) 10.0$ \\
1977 & 1.10 & - \\
1982 & 1.08 & $(-) 1.82$ \\
1987 & 1.00 & $(+) 7.41$ \\
1992 & 1.03 & +3.00 \\
1997 & 0.91 & $(-) 11.65$ \\
2003 & 0.63 & $(-) 30.77$ \\
2007 & 0.52 & $(-) 17.50$ \\
2012 & 0.40 & $(-) 22.63$ \\
\hline
\end{tabular}

Source DAHDF (2014) [19]

increasing trend in adoption of intensive agricultural practices for cash crops due to the availability of canal water in the Thar Desert in the recent past and emergence of new camel diseases, such as camel pox, due to change in the climatic conditions mainly rise in humidity [23].

It has been reported that under very harsh conditions of desert ecosystem, camels have the capability to produce more milk than any other species and having longer lactation period [37], while their feed requirements are modest. Compared to cattle milk, camel milk has lower percentage of fat, total protein and total solids, while having higher percentage of total salts and protective proteins $[16,59,92,114]$. Fresh and fermented camel milks have been used in different regions of the world as a treatment for several diseases.

In India, camel milk is mainly consumed in raw state by the camel rearing societies. However, in recent years, there is a growing tendency among the pastoralist maintaining small- and medium-sized herd to market camel milk in some parts of Rajasthan and Gujarat states [93].

Camel milk has been recognized for its extraordinary medicinal properties. It is known to have a therapeutic potential against many diseases including cancer [42]. It has long been utilized for its beneficial effect in broad range of disease conditions, such as insulin-dependent diabetes mellitus (IDDM) [6], infant diarrhea [121], hepatitis [24, 30], allergy [105], lactose intolerance [28], autism [104] and alcohol-induced liver damage [8]. Its benefits can be attributed to the presence of many immunologically important molecules such as lysozymes, lactoferrin and lactoperoxidase. It contains extraordinarily high levels of insulin-like molecule [6]. Moreover, camel milk has been reported to possess medicinal value against various ailments such as dropsy, jaundice, spleen ailments, tuberculosis, asthma, anemia, piles and food allergies $[44,118]$. It is shown that camel milk has a beneficial action on chronic liver patients, in chronic fatigue and as a supplement to mother's milk [106]. Camel milk is characterized by a relatively powerful protector system compared to milk of other species [71]. The aim of this paper is to review the current knowledge on camel milk production potential, properties and various camel milk products developed at global level.

\section{Milk Production Potential of Camel Breeds}

The annual world production of camel milk is estimated to be 2.9 million tonnes. Somalia is top producer with 1.1 million tonnes followed by Kenya, Mali, Ethiopia Saudi Arabia, Niger, Sudan, UAE, Mauritania and Chad. The total world camel milk production increased by 4.6 times from 629 to 2928 thousand tonnes between 1961 and 2013, mainly due to increase in the production in Africa (Fig. 1). Similarly, it increased to 4.8 times of total African countries, while it is recorded 3.2 times in Asia due to increase in camel population [33]. The overall camel milk production in Asia also increased from 65 to 205 thousand tonnes although there was a decline in the camel population in the region (Table 1).

The highest camel milk yield per animal is recorded to be $971 \mathrm{~kg}$ in Ethiopia followed by camels of Kenya, Qatar, Saudi Arabia, Niger, Somalia, Eritrea, Tunisia,

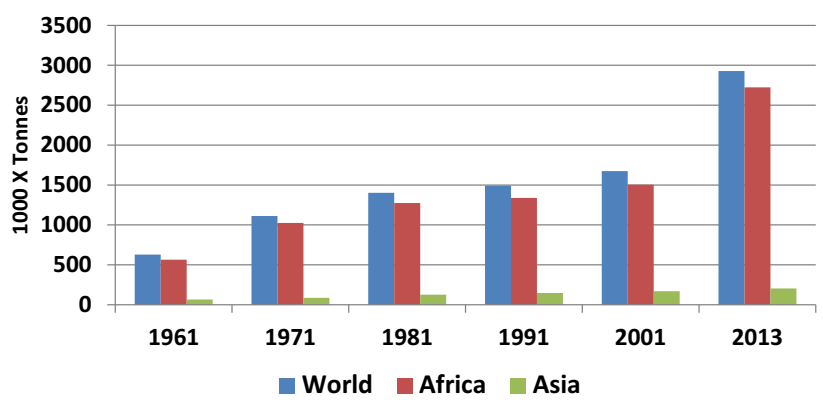

Fig. 1 Growth of global camel milk production 


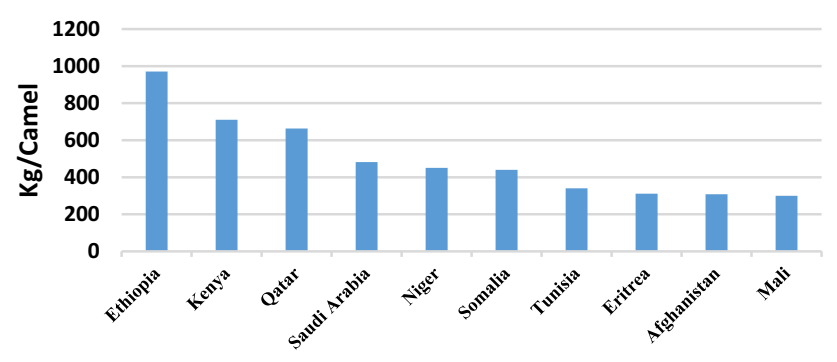

Fig. 2 Productivity per camel in different counties

Afghanistan and Mali [33]. The camel milk yield per animal of top ten countries at global level is presented in Fig. 2. The East African camel breeds such as Rendille, Somali, Turkana and Gabbra are better milk producers compared to the West Asian and North African camel breeds [60].

The Indian main camel breeds, viz. Bikaneri, Jaisalmeri, Kachhchi and Mewari, are shown to produce $3105-4190 \mathrm{~kg}$ milk per lactation at the rate varying from 3.8 to $10.8 \mathrm{~kg} /$ day [71]. The lactation period in the Indian camels can last up to 14-16 months depending upon the time of weaning of the newborn. The average daily milk production by 2 and 4 teat stripping is highest during the 6th month of lactation and with machine milking during the 4th month of lactation. Milking by all three methods indicated morning production to be $12-27 \%$ higher over the evening production, and various factors such as month of lactation, parity, breed and method of milking affect daily milk production $[79,97,98]$. India ranks 7 th in the world in camel milk production, producing around 23.08 thousand tons annually [78].

\section{Camel Milk Properties}

\section{Physicochemical Properties}

Camel milk is opaque white in color, with normal milky odor and salty sweet in taste [21, 92], which mainly depends on the type of fodder or vegetation available in grazing area [58]. The average density of camel milk is $1.029 \mathrm{~g} \mathrm{~cm}^{-3}$ [67]. The viscosity of camel milk at $20{ }^{\circ} \mathrm{C}$ is $1.72-\mathrm{mPa} \mathrm{s}$, whereas the viscosity of bovine milk at the same dry matter content and under same conditions is 2.04$\mathrm{mPa} \mathrm{s}$ [58]. The $\mathrm{pH}$ of fresh camel milk ranges from 6.4 to 6.7 and it is similar to that of sheep milk, but slightly lower than bovine milk. The freezing point of camel milk is between $-0.57{ }^{\circ} \mathrm{C}$ and $-0.61{ }^{\circ} \mathrm{C}$ and it has a calorific value of $665 \mathrm{kcal} / \mathrm{L}$ compared to $701 \mathrm{kcal} / \mathrm{L}$ for cow milk [116]. The difference in calorific value may be attributed with variation in lactose, fat and protein contents as camel milk has comparatively low total milk solids. The water content in camel milk varies from 87 to $90 \%$. An inverse relationship was found between total solids in camel milk and water intake by camel [43].

\section{Shelf Life}

Shelf life of raw camel milk is $8-9 \mathrm{~h}$ at $37{ }^{\circ} \mathrm{C}$ and more than a week at $4-6{ }^{\circ} \mathrm{C}$. Lactoperoxidase system in fresh camel milk was activated within half an hr of the milking using various levels of thiocyanate and hydrogen peroxide (10-70:10-70 ppm ratios) and efficacy was evaluated. The best lowest activation level 20:20 is found to be effective in preserving raw camel milk up to $18-20 \mathrm{~h}$ at $37{ }^{\circ} \mathrm{C}[88,92]$. The enzyme activity in raw camel milk is high and the respective value in pasteurized milk is below the detection limit [91, 92]. In another study, acidity and $\mathrm{pH}$ of the pure fresh camel milk and milk diluted with water (1:1) stored at room temperature were $0.12 \pm 0.03,6.42 \pm 0.18$ and $0.09 \pm 0.02,6.65 \pm 0.22$, respectively. Other parameters, viz. clot on boiling, alcohol and alizarin alcohol tests, were observed negative in fresh camel milk. The study indicated that pure and milk diluted with water (1:1) can be stored for 8 and $10 \mathrm{~h}$, respectively, at room temperature [70].

Postpartum changes in gross chemical composition of camel milk showed an increase in fat from 0.10 to $3.78 \%$, while protein decreased from 17.62 to $2.66 \%$ after 27 days of parturition [92]. The heat coagulation time (HCT) of camel milk at different $\mathrm{pH}$ was recorded to evaluate its suitability for further thermal processing and $\mathrm{pH}$ dependence of heat-induced coagulation. At $\mathrm{pH}$ 6.0, the HCT was observed lowest, while it was highest at $\mathrm{pH}$ 6.8. The HCT of camel milk was stable between $\mathrm{pH} 7.2$ to 7.6 [92].

Evaluation of microbiological quality of camel milk indicated that camel milk can meet the international standards applied for cow milk. The total plate count also met the EU regulation with less than $100,000 \mathrm{cfu} / \mathrm{ml}$ [99]. The camel milk was fermented using four different lactic starter cultures, viz. dahi culture, dahi culture-1, yogurt mix culture and Lactobacillus acidophilus. It was observed that rate of development of acidity is comparatively slow in camel milk than in cattle milk for all the four lactic strains [92].

\section{Gross Chemical Composition}

The composition of camel milk has been evaluated in different parts of world including India with wide variation in data $[77,85,90,108]$. The mean values shown in Table 3 of total solids (11.8\%) of camel milk are slightly lower than that reported in bovine milk (12.33\%), whereas the main components are relatively close to that of bovine milk. Comparative low percentages of total solids and fat 
Table 3 Camel milk composition (gm \%)

\begin{tabular}{|c|c|c|c|c|c|c|}
\hline Country & Protein & Fat & Lactose & Ash & Total solids & Reference \\
\hline China & 3.45 & 4.15 & 4.55 & 0.7 & 8.90 & {$[124]$} \\
\hline East Africa & 2.50 & 3.5 & 3.90 & 0.8 & 11.0 & {$[46]$} \\
\hline Egypt & 3.19 & 5.22 & 5.00 & 0.8 & 14.50 & [113] \\
\hline India & 2.30 & 2.30 & 4.05 & 0.85 & 9.500 & [90] \\
\hline Israel & 4.9 & 3.9 & 5.00 & 0.63 & 13.80 & {$[121]$} \\
\hline Jordan & 2.69 & 2.95 & 3.92 & 0.82 & 12.30 & [43] \\
\hline Kenya & 3.11 & 3.15 & 5.24 & 0.8 & 12.20 & {$[35]$} \\
\hline Kenya & 3.13 & 4.29 & 4.05 & 0.82 & 12.5 & {$[117]$} \\
\hline Libya & 3.30 & 3.3 & 5.61 & 0.82 & 13.00 & {$[41]$} \\
\hline Morocco & 3.36 & 2.74 & 4.19 & 0.86 & 11.10 & {$[95]$} \\
\hline Morocco & 3.25 & 2.65 & 4.05 & 0.83 & 10.80 & {$[62]$} \\
\hline Pakistan & 4.00 & 3.2 & 4.80 & 0.7 & 13.40 & {$[1]$} \\
\hline Pakistan & 3.66 & 3.79 & 5.15 & 0.81 & 13.40 & [109] \\
\hline Saudi Arabia & 2.68 & 3.31 & 4.67 & 0.8 & 11.30 & {$[3]$} \\
\hline Somalia & 3.00 & 5.4 & 3.30 & 0.7 & 13.70 & [47] \\
\hline Sudan & 3.50 & 3.26 & 3.60 & 0.67 & 11.00 & {$[2]$} \\
\hline Tunisia & 2.81 & 1.2 & 5.40 & 0.99 & 9.60 & [13] \\
\hline Mean & 3.26 & 3.29 & 4.55 & 0.78 & 11.80 & \\
\hline SD & \pm 0.62 & \pm 0.91 & \pm 0.74 & \pm 0.09 & \pm 1.55 & \\
\hline
\end{tabular}

Table 4 Comparative analysis of milk protein and fat in different Indian camel breeds

\begin{tabular}{llll}
\hline Parameters (gm \%) & \multicolumn{3}{l}{ Indian camel breeds } \\
\cline { 2 - 4 } & Bikaneri & Jaisalmeri & Kachchhi \\
\hline Protein & $3.61 \pm 0.03$ & $3.37 \pm 0.04$ & $4.22 \pm 0.03$ \\
Fat & $2.47 \pm 0.16$ & $2.99 \pm 0.20$ & $1.95 \pm 0.12$ \\
\hline
\end{tabular}

in camel milk have definite positive benefits of drinking camel milk over cow milk.

However, variations observed in camel milk composition could be attributed to several factors such as analytical measurement procedures, geographical locations, feeding conditions and samples being taken from different breeds, in addition to other factors including stage of lactation, age and calving number [58]. Geographical origin and seasonal variations are found to be the most effective factors in camel milk composition.

\section{Proteins}

The average protein content of milk is recorded comparatively more in Kachchhi breed followed by Bikaneri and Jaisalmeri breeds (Table 4). Similar trend was observed for the casein content [39, 57]. Konuspayeva et al. [59] reported total protein content of camel milk varying from
2.1 to 4.9 percent. Protein denaturation temperature for rennet and acid whey are reported as 73.8 and $60.50{ }^{\circ} \mathrm{C}$ for camel and 70.5 and $63.9^{\circ} \mathrm{C}$ for cow [39]. Casein $(\mathrm{CN})$ is the major protein (1.63-2.76\%) in camel milk and constitutes about $52-87 \%$ of the total proteins. The $\beta-\mathrm{CN}$ content is higher than $\alpha-\mathrm{CN}$ and $\beta-\mathrm{CN}$, and $\alpha-\mathrm{CN}$ constitutes about 65 and $21 \%$ of total casein, respectively, compared with 36 and $38 \%$ in bovine milk, respectively [55]. The $\kappa$-casein content of camel milk is about $3.47 \%$ of the total casein compared with $13 \%$ in bovine milk [20]. This affects some of the processing characteristics, heat treatment and enzymatic coagulation of casein micelles in camel milk.

Whey proteins constitute about $20-25 \%$ of the total proteins and ranges from 0.63 to $0.80 \%$ of the milk $[58,70,77]$. Four major whey protein fractions are present in camel milk [34, 77]. Comparative studies indicate marked difference in whey protein profiles of camel and cow milk. The $18.5 \mathrm{kDa}$ whey protein with the characteristics of $\beta$-lactoglobulin though isolated from bovine, ovine and caprine milk has not been reported in camel milk [34], while $\sim 23 \mathrm{kDa}$ whey protein is expressed in camel milk and is not present in cow milk [77]. Of the two major whey proteins, $\alpha$-lactalbumin is the main component in camel milk, while $\beta$-lactoglobulin is deficient [67]. Other whey proteins present in camel milk are serum albumin, lactoferrin, immunoglobulins and peptidoglycan recognition protein [56]. The ratio of whey protein to casein is higher in camel milk than in cow milk. This may explain why the 
Table 5 Comparative analysis of camel milk according to geographical origins

\begin{tabular}{llll}
\hline Parameters (gm \%) & \multicolumn{3}{c}{ Major geographical origins } \\
\cline { 2 - 4 } & East Africa & North Africa & Western Asia \\
\hline Protein & $3.33 \pm 0.52$ & $3.21 \pm 0.60$ & $3.10 \pm 0.62$ \\
Fat & $4.41 \pm 0.80$ & $3.50 \pm 1.01$ & $3.30 \pm 1.03$ \\
\hline
\end{tabular}

coagulum of camel milk is softer than that of cow milk. The variability of camel milk composition clearly depended on geographical origin as it is recorded highest in East Africa followed by North Africa and Western Asia (Table 5).

\section{Fats}

The fat content of camel milk is between 1.2 and 5.4\% [60] with an average of $3.29 \%$ (Table 3) which depends upon level of nutrition, stage of lactation, breed, season, etc. [92]. Comparatively more fat content is observed in Jaisalmeri breed followed by Bikaneri and Kachchhi breeds [73]. A strong positive correlation is found between fat and protein contents [43]. Fat content of camel milk was reported to decrease from 4.3 to $1.1 \%$ in milk produced by thirsty camels [121]. However, the fat globules of camel milk are smaller in size but have highest fat digestibility than buffalo, followed by cow and goat milks [112]. Camel milk fat has a lower content of carotene as compared to bovine milk [76]. The cholesterol contents in camel milk $(5.64 \pm 3.18 \mathrm{mg} / 100 \mathrm{~g}$, SD) are not significantly lower than in cow milk $(8.51 \pm 9.07 \mathrm{mg} / 100 \mathrm{~g}, \mathrm{SD})$. Fat content in cow milk is higher and cholesterol/fat ratio is similar in the two species (camel: $225 \pm 125 \mathrm{mg} / 100 \mathrm{~g}$ fat; cow $211 \pm 142 \mathrm{mg}$ / $100 \mathrm{~g}$ fat), while the serum cholesterol concentration is significantly higher in cow $(227.8 \pm 60.5 \mathrm{mg} / 100 \mathrm{ml})$ than in camel $(106.4 \pm 28.9 \mathrm{mg} / 100 \mathrm{ml})$ [38]. The storage stability of freeze-dried camel milk fat is more as compared to cream. It is observed that the melting of fat in cream has low melting temperature $-12{ }^{\circ} \mathrm{C}$ as compared to the pure fat at $-5{ }^{\circ} \mathrm{C}$. This decrease in melting temperature could be due to the effects of protein content in the cream [94].

Data presented in Table 6 indicate that higher content of long-chain fatty acids (C14-C18) and lower content of short-chain fatty acids $(\mathrm{C} 4-\mathrm{C} 12)$ are present in camel milk compared to cow milk [4, 43, 92]. Camel milk fat is characterized by higher proportion of unsaturated $[4,43]$ as well as long-chain fatty acids compared with other species. Unsaturated FA in camel milk $(65.02 \mathrm{~g} / 100 \mathrm{~g} \mathrm{FA})$ is highest followed by the cow milk $(40.76 \mathrm{~g} / 100 \mathrm{~g})$, goat milk (40.23 g/100 g) and $58.17 \mathrm{~g} / 100 \mathrm{~g}$ human milk [114]. Generally, camel milk is considered as a rich source of
Table 6 Fatty acids concentration (gm \%) of camel milk

\begin{tabular}{|c|c|c|c|c|c|}
\hline \multicolumn{2}{|l|}{ Fatty Acid } & \multicolumn{4}{|c|}{ Reference number } \\
\hline Common name & Formula & {$[35]$} & {$[4]$} & {$[41]$} & {$[57]$} \\
\hline Butyric & C 4:0 & 0.66 & 3.5 & 1.0 & 0.048 \\
\hline Caproic & C 6:0 & 0.33 & 2.1 & - & 0.229 \\
\hline Caprylic & C 8:0 & 0.23 & 1.4 & 0.5 & 0.166 \\
\hline Capric & C 10:0 & 0.90 & 2.1 & 0.1 & 0.110 \\
\hline Lauric & C 12:0 & 0.79 & 3.1 & 0.5 & 0.060 \\
\hline Myristic & C 14:0 & 12.5 & 10.0 & 10.0 & 0.206 \\
\hline Myristoleic & C $14: 1$ & 1.1 & 1.70 & 1.5 & 0.066 \\
\hline Palmitic & C 16:0 & 31.5 & 26.60 & 31.5 & 0.529 \\
\hline Palmitoleic & C $16: 1$ & 9.4 & 1.70 & 9.0 & 0.403 \\
\hline Stearic & C 18:0 & 12.50 & 7.86 & 14.0 & 0.151 \\
\hline Oleic & C $18: 1 n 9$ & 19.1 & 29.0 & 25.0 & 0.495 \\
\hline Linoleic & C $18: 2 n 6 c$ & 3.4 & 3.2 & 3.0 & 0.047 \\
\hline Arachidic & C 20:0 & 1.03 & 0.11 & 0.50 & 0.067 \\
\hline
\end{tabular}

long-chain fatty acids (92-99\%) and unsaturated fatty acids that reduce human serum lipids and decreases the incidence of lipid-related cardiovascular diseases (35-50\%) [57]. Unsaturated fatty acids are inversely associated with diabetes risk [74]. Further, the conjugated linoleic acid plays an important role in prevention and treatment of diabetes [103].

\section{Lactose}

In all the mammals, lactose is main carbohydrate in milk. The lactose content of camel milk ranges between 2.40 and $5.80 \%$ [60]. The variation would be because camels usually graze on wide variation in arid plants and salty bushes available in desert [58]. In meta-analysis, study of lactose correlation with fat matter is found negative, while no correlation between total protein and lactose is observed [60]. It remains almost unchanged over a season [43] and under hydrated or dehydrated conditions [121] though it is only found to change slightly for camel milk of some camel breeds in different part of the world [77]. The lactose content of camel milk (4.2\%) is reported to be lower than that of bovine milk (4.9\%) [110], whereas buffalo milk is found to contain lower lactose compared to camel milk as well as cow milk [52].

\section{Minerals}

The total mineral content as total ash ranged from 0.60 to $0.90 \%$ in dromedary camel milk $[34,60]$. Camel milk is a rich source of chloride [58] due to the forage eaten by camels such as Atriplex and Acacia, which usually have a 
Table 7 Mineral content (gm \%) in camel and cow milk

\begin{tabular}{llrrrl}
\hline $\mathrm{P}$ & $\mathrm{Na}$ & \multicolumn{1}{c}{$\mathrm{K}$} & $\mathrm{Ca}$ & $\mathrm{Mg}$ & Reference no. \\
\hline 84 & 59 & 173 & 115 & 14 & {$[3]$} \\
58 & 36 & 60 & 132 & 16 & {$[41]$} \\
71 & 36 & 62 & 116 & 08 & {$[46]$} \\
63 & 69 & 156 & 106 & 12 & {$[76]$} \\
90 & 46 & 29 & 84 & 3 & {$[92]$} \\
96 & 58 & 128 & 124 & 12 & {$[77]$} \\
\hline
\end{tabular}

high salt content [119] and may be one of the reasons of salty taste of milk [123]. The macromineral content of camel milk varied between breeds, such as Majaheim, Najdi, Wadah and Hamra [77] and Bikaneri, Jaisalmeri and Kachachhi [72, 73]. The concentration of other macrominerals, namely $\mathrm{Ca}, \mathrm{Mg}, \mathrm{P}, \mathrm{Na}$ and $\mathrm{K}$, in camel milk is almost comparable to those of cow milk (Table 7). The major reasons of variations in mineral content reported are due to breed differences, feeding, analytical procedures and water intake [43].

Camel milk is rich in $\mathrm{Zn}, \mathrm{Fe}, \mathrm{Cu}$ and $\mathrm{Mn}$ than cow milk [92]. The values of trace minerals, viz. $\mathrm{Fe}, \mathrm{Zn}$ and $\mathrm{Cu}$, reported in camel and bovine milks are 1.37, 2.19 and $0.44 \mathrm{mg} / \mathrm{dl}$ and $0.05,0.35$ and $0.02 \mathrm{mg} / \mathrm{dl}$, respectively [40]. The ratio of $\mathrm{Ca}$ to $\mathrm{P}$ is 1.5 for camel milk verses 1.29 and 2.1 for cow and human milk, respectively. This ratio is of significant importance since cow milk-based formula used for feeding infants contains high phosphate, which may lead to hyperphosphatemia and low serum calcium [114].

\section{Vitamins}

Among the water-soluble vitamins, camel milk is rich in niacin and vitamin $\mathrm{C}$ content. It is revealed that camel milk contained three to five times [111] more vitamin $\mathrm{C}$ as compared to bovine milk. The mean value of vitamin $\mathrm{C}$ concentration present in camel milk is $34.16 \mathrm{mg} \cdot \mathrm{L}^{-1}$. The availability of relatively higher amount of vitamin $\mathrm{C}$ in raw camel milk is of significant relevance from the nutritional point as vitamin $\mathrm{C}$ exhibits powerful antioxidant action and it can be an alternative source of vitamin $\mathrm{C}$ under harsh environmental conditions in the arid and semiarid areas $[72,73]$.

Vitamin $B_{1}, B_{2}$, folic acid and pantothenic acid are low in camel milk, while $\mathrm{B}_{6}$ and $\mathrm{B}_{12}$ content is quite similar to that of cow milk but higher than in human milk. The content of vitamin A $(100-380 \mu \mathrm{g} / \mathrm{L})$ in camel milk is reported to be lower than that of bovine milk [114]. The levels of vitamin $\mathrm{A}, \mathrm{E}$ and $\mathrm{B}_{1}$ were reported to be low in camel milk compared to cow milk [114]. Concentration of vitamins $\mathrm{A}, \mathrm{E}$ and $\mathrm{B}_{1}$ was as $20.1 \pm 10.0 \mu \mathrm{g} \%$, $32.7 \pm 12.8 \mu \mathrm{g} \%$ and $19.6 \pm 6.4 \mathrm{mg} \%$ in camel milk as compared to $60.9 \pm 25.6 \mu \mathrm{g} \%, 171.0 \pm 114.4 \mu \mathrm{g} \%$ and $34.7 \pm 8.1 \mathrm{mg} \%$, respectively, in cow milk. Cow milk contains $99.6 \pm 62.0 \mu \mathrm{g} \% \quad \beta$-carotene, but it is not detected in camel milk.

According to the USDA report 2009, $250 \mathrm{ml}$ camel milk provide an adult with about $15.5 \%$ of cobalamin $\left(\mathrm{B}_{12}\right)$, $8.25 \%$ of riboflavin $\left(B_{2}\right), 5.25 \%$ of vitamin $A$ and $10.5 \%$ of ascorbic acid $(C)$, thiamin $\left(B_{1}\right)$ and pyridoxine $\left(B_{6}\right)$ of the recommended daily intake (RDI) [10].

\section{Milk Enzymes, Protective Protein and Hormones}

The enzyme activity of gamma glutamyl transferase (GGT), lactate dehydrogenase (LDH), lactoperoxidase and catalase in camel milk were $241 \pm 13.55 \mathrm{IU} / \mathrm{L}, 140$ $\pm 15.08 \mathrm{IU} / \mathrm{L}, 2.2 \pm 0.30 \mathrm{unit} / \mathrm{ml}$ and $0.128 \pm 0.025 \mathrm{~mol} /$ $\mathrm{min} / \mathrm{gm}$ of protein, respectively [88]. Camel milk contains a number of protective proteins, mainly enzymes that exert antibacterial and immunological properties, viz., lysozyme, lactoferrin, lactoperoxidase and peptidoglycan recognition protein (PGRP). PGRP has not been detected in cow milk. This enzyme has broad antimicrobial activity and has ability to control the cancer metastasis. Immunological research on camel milk lysozyme revealed that there is no antigenic resemblance between bovine and camel milk lysozyme, indicating alike structures. The level of lysozyme in milk differs extensively from $79 \mathrm{mg} 100 \mathrm{~mL}^{-1}$ in mare milk [51] to $13 \mu \mathrm{g} 100 \mathrm{~mL}^{-1}$ in buffalo milk [27]. Lysozyme activity of camel milk ranged from 0.03 to $0.65 \mathrm{mg} / \mathrm{dl}$ [73]. According to different researches, camel milk contains 228 and $500 \mu \mathrm{g} 100 \mathrm{~mL}^{-1}$ of lysozyme [22, 27] compared to 13 and $37 \mu \mathrm{g} 100 \mathrm{~mL}^{-1}$ in cow milk [61]. The variations in the observed values were mainly due to the effect of lactation period. The camel milk/colostrum contains higher concentration of lactoferrin and lysozyme than in cow milk. Lactoperoxidase present in camel milk is a monomeric protein, which shows about $79.2 \%$ sequence likeness to human eosinophil peroxidase and $79.3 \%$ sequence likeness to human myeloperoxidase. Both eosinophil peroxidases and myeloperoxidase are dimeric proteins [53]. Lactoperoxidase was extracted and purified from bovine and camel milk and their molecular weights were approximated at 88 and $78 \mathrm{kD}$ a, respectively [122]. The activity of lactoperoxidase in camel milk was found to be $2.23 \pm 0.01$ units $/ \mathrm{ml}$ of milk.

Immunoproteins $\operatorname{IgG}, \operatorname{Ig} \mathrm{A}, \operatorname{IgM}, \mathrm{C} 3$ and $\mathrm{C} 4$ in milk were determined to study antibacterial factors. The values of these proteins in camel milk are $2799 \pm 71.2,210 \pm 21.0$, 
$84 \pm 15.9,3.3 \pm 0.25$ and $0.5 \pm 0.14 \mathrm{mg} / \mathrm{dl}$, respectively [92].

Camel milk samples from different stages of lactation were processed for determination of progesterone, prolactin, TSH, cortisol and insulin using radioimmunoassay method. The values of prolactin, insulin, TSH, progesterone and cortisol ranged from 8 to $11 \mathrm{ng} / \mathrm{ml}, 45$ to 128 $\mathrm{uU} / \mathrm{ml}, 0.12$ to $0.15 \mathrm{uIU} / \mathrm{ml}, 0.35$ to $0.1 .40 \mathrm{ng} / \mathrm{ml}$ and 25 to $34 \mathrm{ng} / \mathrm{ml}$, respectively [92].

\section{Functional Properties and Medicinal Applications of Camel Milk}

Camel milk as good alternative to cow milk for human nutrition has been acknowledged for a long time in different parts of the world [111]. There are reports that camel milk acts as an adjuvant and has medicinal properties, suggesting it contains protective proteins, which may have possible role for enhancing immune defense mechanism [120]. These potential health benefits are obtained through a number of bioactive components in camel milk [63, 65]. These components either exist naturally in camel milk or are derived from camel milk protein hydrolysates using proteolytic enzymes and/or fermentation with lactic acid bacteria $(\mathrm{LAB})[64,66]$.

\section{Antimicrobial Properties}

\section{Antiviral Activity}

Rotaviruses are the most frequent cause of nonbacterial gastroenteritis in infants or calves in most parts of the world. Camel milk-purified immunoglobulin ( $\mathrm{IgG}$ ) and secretory immunoglobulin A (sIgA) are reported to be effective against rotaviruses isolated from bovine [26] or form human sources [25]. The antirotavirus activity, i.e., antibody titer in colostrum, was strong due to IgG, while sIgA in normal milk was high. This indicates that raw camel milk is considered a strong viral inhibitor to human rotavirus. These findings may explain the reason for use of camel milk as a remedy to treat diarrhea by camel herdsmen [25, 26].

Freshly prepared or preserved 'Shubat,' a fermented camel milk drink used in Kazakhstan, has been reported to possess virucidal and virus-inhibiting properties against ortho- and paramyxoviruses [18]. These properties are retained during storage. The antiviral activity of 'Shubat' is suggested to be due to the presence of sialic conjugates and metabolic products of lactic acid bacteria and yeasts.

The ability of camel milk proteins to inhibit and/or blocking the hepatitis $\mathrm{C}$ virus (HCV) entry and replication inside the cell system has been reported. Camel lactoferrin demonstrated a remarkable in vitro ability to completely inhibit the HCV entry and replication into human peripheral blood mononuclear cells (PBMC), hepG2 and replication inside those cells system [30].

\section{Antibacterial Activity}

Camel milk is reported to inhibit both gram-positive and gram-negative bacteria, including Escherichia coli, Listeria monocytogenes, Staphylococcus aureus and Salmonella typhimurium [26, 63, 64]. The inhibitory action of camel milk against L. monocytogenes, S. aureus and E. coli has been attributed to the presence of lactoperoxidase, hydrogen peroxide and lysozyme, respectively. The growth of Salmonella typhimurium is inhibited by lactoferrin in camel milk through binding iron and making it unavailable for its growth [26, 84]. It is demonstrated that the potential for camel lactoferrin to inhibit $\mathrm{HCV}$ entry into human leukocytes is with more efficiency than human or bovine lactoferrin [31]. The potential of camel milk lactoferrin for its ability to inhibit the proliferation of the colon cancer cell line has been reported [42]. The concentration of lysozyme, lactoferrin and immunoglobulins in camel milk is higher than in bovine or buffalo milk [30, 68]. The antimicrobial activity of these molecules is, however, lost in camel milk after heat treatment at $100{ }^{\circ} \mathrm{C}$ for $30 \mathrm{~min}$ [25].

\section{Camel Milk as an Adjuvant for Human Tuberculosis Patients}

Camel milk has been used for the treatment of different types of human tuberculosis, viz. empyema, fresh, chronic pulmonary and multiple drug-resistant (MDR) patients [71]. Male inpatients who suffered from tuberculosis were divided into camel milk supplemented and control groups. The clinical symptoms revealed no cough, expectoration and breathlessness, hemoptysis and fever in camel milk supplemented group. However, control group patients indicated persistence of cough and breathlessness. Comparatively more improvement in hematological and radiological observations was found in camel milk supplemented patients. The concentration of serum $\mathrm{Zn}$ and $\mathrm{Fe}$ was significantly $(P<0.01)$ higher in the patients supplemented with camel milk. Increase in the serum $\mathrm{Zn}$ concentration ranged from 20.38 to $44.97 \%$ and 6.94-10.79\%, and the increase in serum iron was 14.92-20.92 and $6.98-9.29 \%$, respectively, in camel milk supplemented and control groups. Serum copper $(\mathrm{Cu})$ was estimated and percent decrease in the level of $\mathrm{Cu}$ was found to be 50.25 and $21.54 \%$ in camel milk supplemented and control groups, respectively. The body weight gain ranged from 6.48 to 
$20.68 \%$ in camel milk group and 3.38 to $4.70 \%$ in control group. Immunoglobulins status studied in MDR tuberculosis patients indicated that the levels of infection as specified by $\mathrm{IgG}$ and IgA in the patients of camel milk group also decreased in comparison with control group. As regards IgM antibody status, $62.50 \%$ patients of camel milk group were found to be negative; however, control group remained positive at the end of trial. Decrease in the level of IgA was 45.18 and $35.36 \%$ in camel milk and control group, respectively. Decrease in the level of IgG was 65.25 and $41.55 \%$ in camel milk and control groups, respectively. The results pertaining to clinical, bacteriological and radiological attributes indicated higher improvement in the camel milk supplemented group as compared to control group. It can be concluded from the above studies that raw camel milk along with normal therapy helps in fast recovery of tuberculosis and camel milk can act as an adjuvant nutritional supplement in tuberculosis patients.

\section{Protection Against Lead Contamination}

Protection against lead contamination by strains of lactic acid bacteria from fermented camel milk has been reported [9]. One of the most frequently described problems in lead toxicity is saturnism, cancer and anemia. Camel milk and fermented 'Shubat,' its derivative product, contaminated with the lactic fermentation of 'Shubat,' could reduce the availability of lead in digestive tract of consumers because LAB is able to absorb this metal which is then excreted in the feces.

\section{Angiotensin I-Converting Enzyme (ACE) Inhibitory Activity}

ACE-inhibitory peptides are present in the primary structure of various food protein sources including milk proteins $[50,69,80,81]$. These peptides are also found in fermented camel milk [86]. Probiotic bacteria have been shown to hydrolyze the major components of milk proteins to increase the number of peptides and amino acids to enable their growth [11]. Lactobacillus helveticus 130B4 was used to release the ACE-inhibitory peptides from camel milk proteins; the amino acid sequence was identified as Ala-IlePro-Pro-Lys-Lys-Asn-Gln-Asp [86].

The ACE-inhibitory activity of camel milk protein hydrolysates has also been studied and reported that after enzymatic hydrolysis of camel milk proteins, the ACEinhibitory activities of camel whole casein and camel $\beta-\mathrm{CN}$ were enhanced. Camel whole casein and $\beta-C N$ showed significant ACE-inhibitory activities after hydrolysis with pepsin alone and after pepsinolysis followed by trypsinolysis and chymotrypsinolysis [101].
Recently the ACE-inhibitory activity of peptide fractions from bovine and camel milk fermented by Lactobacillus rhamnosus PTCC 1637 was compared. Higher ACE-inhibitory was observed from cultured camel milk than bovine milk. This may be explained by structural differences and the presence of higher proline content in the primary structure of camel milk caseins compared to bovine milk [81].

\section{Camel Milk Adjuvant for Management of Diabetes}

The presence of high concentration of insulin/insulin-like substances in camel milk such as half-cystine [15], the effect of small-sized immunoglobulins of camel milk on $\beta$ cell [7] and the lack of coagulation of camel milk in the human stomach contribute to the hypoglycemic effect in type 1 diabetes in human [6], rats [99] as well as in alloxaninduced diabetic dogs [102].

Oral insulin has been known since many years, but the critical drawback is its coagulation in acidic media in the stomach, which neutralizes its potency. One property of camel milk is that it does not form the coagulum in the stomach or the acidic media; therefore, it prevents degradation of insulin in the stomach. It was found that amino acid sequence of some of the camel milk protein is rich in half cysteine, which has similarity with insulin family of peptides [48]. The lack of coagulum formation allows the camel milk to pass rapidly through the stomach together with the specific insulin or insulin-like peptide and remains available for absorption in intestine.

Poor sensitivity to insulin is typically associated with type 2 diabetes, but it also plays a key role in brain signaling. Reducing the level of insulin in the brain immediately impairs cognition and spatial memory seems to suffer in insulin deficiency. It is reviewed that camel milk has powerful effect in reducing in blood glucose levels and insulin requirement. Camel milk is safe and efficient in improving long-term glycemic control and can provide significant role management of type 1 diabetic patients [107]. Recently, it has been observed that Alzheimer's can be considered as a type of diabetes and termed as type 3 diabetes. As camel milk contains very high amount of insulin, it could be useful for the treatment of type 3 diabetes. However, further comprehensive studies are needed in this regard.

\section{Camel Milk Safe for People Allergic to Bovine Milk}

Camel milk is recently suggested as an alternative food to children with allergenicity to bovine milk. Hypoallergenicity of mothers' milk was reported to be due to the 
high percentage of $\beta-\mathrm{CN}$, low percentage of $\alpha-\mathrm{CN}$ [28], deficiency of $\beta$-lactoglobulin [54] and similarity of the immunoglobulins [105]. It has been reported that camel milk could be a new protein source for children allergic to bovine milk. It is expected to cause little hypersensitivity reactions because camel milk proteins and their percentages are similar to that found in human milk [28].

\section{Antiatherosclerosis Property}

Fermented camel milk (gariss) and 'gariss' containing $B i$ fidobacterium lactis (BB-12) administration has been reported to possess a hypocholesterolemic effect in vivo in rats [29]. The hypocholesterolemia mechanism of camel milk is still unclear, but different hypotheses have been proposed, including: interaction between bioactive peptides derived from camel milk proteins and cholesterol, which result in cholesterol reduction [68], and the presence of orotic acid in camel milk which is thought to be responsible for lowering cholesterol level in human subjects [17] and in rats [96].

\section{Antioxidant Activity}

Salami et al. [100] studied the enzymatic digestibility and antioxidant activity of camel $\alpha$-lactalbumin. Camel $\alpha$-lactalbumin showed higher degrees of hydrolysis (digestibility) with both trypsin and chymotrypsin enzyme than bovine $\alpha$-lactalbumin, but both proteins showed similar sensitivity to pepsin enzyme. The antioxidant activity of camel $\alpha$-lactalbumin was greater than that of bovine $\alpha$ lactalbumin because it contains higher antioxidant amino acids residues, in addition to the differences in conformational features of both proteins.

The effects of enzymatic hydrolysis with digestive enzymes of camel whole casein and $\beta-\mathrm{CN}$ on their antioxidant properties were studied. After enzymatic hydrolysis, antioxidant activities of camel whole casein [65] and camel $\beta-\mathrm{CN}$ were enhanced. Camel $\beta-\mathrm{CN}$ showed high antioxidant activity after hydrolysis with chymotrypsin. The results of this study suggest that when camel milk is consumed and digested, the produced peptides start to act as natural antioxidants $[65,66,101]$.

In a recent study, the antioxidant activity of peptide fractions from bovine and camel milk fermented by Lactobacillus rhamnosus PTCC 1637 was compared. Higher antioxidant activity was observed from cultured camel milk than bovine milk [81]. In both the milks, increased proteolytic activity during storage resulted in increased antioxidant activity.

\section{Development of Camel Milk Products}

Various products produced from camel milk include soft cheese [32, 49, 75], fermented milk [29], yoghurt [45], ice cream [5] and butter [36]. The commercial production of camel cheese is also possible by using active camel chymosin produced by expression in yeast strain, Pichia pastoris GS115 [115].

Milk fatty acid composition is one of the aspects related to the health effects of camel's milk and its products. However, the fatty acid composition of camel milk is not well documented [8]. Human milk fat contains a higher content of unsaturated fatty acids compared with bovine, but camel's milk seems to be very different from other mammalian milks in terms of unsaturated fatty acid composition and in its low content of short-chain fatty acids.

Camel milk contains less fat, which mainly consists of polyunsaturated fatty acids that are completely homogenized and gives the milk a smooth white appearance. Lactose is present in concentrations of $4.8 \%$ and is easily metabolized by persons suffering from lactose intolerance [12]. Value additions of camel milk can be an alternative to make it more important in daily life. By-products can be prepared and stored for longer period for transportation. Most camel milk is consumed raw, boiled or for preparation of tea. Nowadays, low-fat dairy products are preferred over full fat products in several markets. This trend has been particularly visible for ice cream over the last few years. Camel milk being low in fat also contains vitamin B, iron and unsaturated fatty acids. Camel ice cream is safe for consumers with lactose intolerance and contains 3 times more vitamin $\mathrm{C}$ than cow milk [4].

Fermented raw camel milk products, such as 'gariss' in Sudan or 'suusac' in Kenya and Somalia, which are often initiated through continuous utilization of vessels and back slopping, play an important role in the diet of pastoral communities [37]. Camel milk is also used for the preparation of 'kheer,' and it is very much famous among the Rakia's community of Rajasthan, India.

Various camel milk products were prepared and assessed at NRC on Camel, Bikaner. The products include ice cream/kulfee, frozen desserts with different flavors [87, 89, 92], camel milk tea and coffee, fermented milk/ curd, butter and ghee, flavored milk, paneer, cheese, khoa/mawa, gulabjamun, barfi/chocolate barfi, peda, lyophilized whole and skim milk powder, chocolates and human skin cream [87, 91-93]. Processing technologies for the manufacture of rasogolla, sandesh, rabri from fermented camel milk; sweet lassi, frozen yoghurt with oat flour, frozen yoghurt with improved texture, camel milk whey drink and spray dried milk powder were standardized [92]. Camel milk creams have a healing effect on skin 
autoimmune diseases. Phenotypic and genotypic characterization of lactobacilli isolated from camel milk cheese produced by NRC on Camel, Bikaner, revealed that these isolates have potential for development of defined strain starter for camel cheese [82].

\section{Commercial Viability of Camel Milk and its Value-Added Products}

In order to popularize and promote the camel milk and milk products, viz., kulfee, flavored milk, lassi, tea and coffee, these were prepared and sold in the camel milk parlor started by NRC, Bikaner [92]. Camel milk and milk products were sold for more than thirty lakhs of rupees during the period from April 2007 to March 2017 period. The results of beneficial effects of camel milk in patients suffering from autism and other ailments justify further need to organize camel milk trading in the country. Looking to benefit the autistic children, a pilot research trial in collaboration with Baba Farid Centre for Special Children (BFCSC) Faridkot is under taken in line of future commercialization. Similarly, technologies for the production of lyophilized camel milk powder and flavored camel milk are under the process of MoU with NGO and dairy industry for their commercialization.

\section{Bactrian Camel Milk Production and Composition}

Milk production potential of Bactrian camel has been reported to be low (0.5-1 L/day) as compared to dromedaries, but it has been also reported from Kazakhstan that these camels produce as high as 6-7 L of milk/day, which is higher than the milk production potential of local cows and dromedaries [70].

The percent value of protein, lactose, fat, ash and total solids in colostrum of Bactrian camel are 14.23, 4.44, 0.27, 0.77 and $20.16 \%$, respectively, whereas in the milk these values were $3.55,4.24,5.65,0.87$ and $14.31 \%$, respectively [123]. The percent value of protein, lactose, fat, ash and total solids in Chinese Bactrian camel milk are 3.90, 4.50, 5.32, 0.83 and 14.52, respectively [124] The $\mathrm{pH}$, acidity $(\%)$, density, viscosity (mPa s), electrical conductivity ( $\mu \mathrm{S} /$ $\mathrm{cm}$ ) of regular fresh Bactrian camel milk ranged from 6.37 to $6.57,0.17$ to $0.20,1.028$ to $1.040,6.79$ to 7.16 and 0.380 to $0.547 \times 10^{4}$, respectively [124]. The Alxa Bactrian had stronger buffering capacity than that of bovine milk [14].

The Bactrian camel's milk is high in fat because these animals live in a cold desert environment and higher fat provides more energy to the suckling calves. The fat quantity in milk also depends upon the availability of water [72]. Milk fat composition revealed that the ratio of $\mathrm{C} 12: 0$ to $\mathrm{C} 18: 0$ saturated fatty acids in colostrum was lower than that of regular milk and the predominant saturated fatty acids were $\mathrm{C} 14: 0, \mathrm{C} 16: 0$ and $\mathrm{C} 18: 0$, despite the lactation phase. Considerable level of polyunsaturated fatty acid (C18:1) was also reported in Bactrian milk [83, 123]. The composition of fatty acids in Bactrian camel showed slight differences than to dromedary milk. Dromedary milk contains higher amount of $\mathrm{C} 10, \mathrm{C} 18$ and $\mathrm{C} 18: 1(\mathrm{n}-7)$, while Bactrian milk is richer in $\mathrm{C} 14, \mathrm{C} 16$ and $\mathrm{C} 18: 1$ (n-9) $[4,43]$. The levels of $\mathrm{Ca}, \mathrm{P}, \mathrm{Na}, \mathrm{K}$ and $\mathrm{Cl}$ were 222.58 , $153.74,65.0,136.5$ and $141.1 \mathrm{mg} / 100 \mathrm{~g}$, respectively, in colostrum and 154.57, 116.82, 72.0, 191.0 and $152.0 \mathrm{mg} /$ $100 \mathrm{~g}$, respectively, in the Bactrian camel milk [123]. The levels of vitamins $\mathrm{A}, \mathrm{C}, \mathrm{E}, \mathrm{B}_{1}, \mathrm{~B}_{2}, \mathrm{~B}_{6}$ and $\mathrm{D}$ were 0.97 , $29.60,1.45,0.12,1.24,0.54 \mathrm{mg} / \mathrm{L}$ and $640 \mathrm{IU} / \mathrm{L}$, respectively, in milk. Levels of vitamin A and C contents in milk were higher, whereas amount of vitamins $\mathrm{E}$ and $\mathrm{B}_{1}$ were lower than those in colostrums [123].

\section{Conclusions}

Fresh camel milk and their products are a good bioactive adjuvant for the people living in the arid and semiarid areas. Awareness and utilization of camel milk as health adjuvant are gradually increasing as the camel milk has been found to have unique properties of its proteins, fatty acids, richer in microminerals and vitamin C compared to milks of other animal species, such as bovine milk. Further studies are required to characterize fat globule membrane, bioactive proteins and peptides. Work is also warranted on camel milk protein coagulation by acid and chymosin enzyme to solve problems associated with cheese making. Fresh and fermented camel milk are reported for improving immunity and provides particular health benefits to the consumer depending on the unique bioactive substances in milk. More extensive research investigations are required to confirm the projected health benefits and characterize the properties of this natural adjuvant, to create economic and social space for camel milk and products. This review is expected to open new avenues for developing modern camel dairies and generate greater interest in camel milk research.

\section{Compliance with Ethical Standards}

Conflict of interest All authors declare that they have no conflict of interest.

Open Access This article is distributed under the terms of the Creative Commons Attribution 4.0 International License ( http://creativecommons.org/licenses/by/4.0/), which permits unrestricted use, distribution, and reproduction in any medium, provided you give appropriate credit to the original author(s) and the source, provide a link to the Creative Commons license, and indicate if changes were made. 


\section{References}

1. Abdel-Rahim AG (1987) The chemical composition and nutritional value of camel (Camelus dromedarius) and goat (Capra hirchus) milk. World Rev Anim Prod 23:9-11

2. Abdoun KA, Amin ASA, Abdelatif AM (2007) Milk composition of Dromedary camels (Camelus dromedarius): nutritional effect and correlation to corresponding blood parameters. Pak J Biol Sci 10:2724-2727

3. Abu-Lehia IH (1987) Composition of camel milk. Milchwissenschaft 42:368-371

4. Abu-Lehia IH (1989) Physical and chemical characteristics of camel milk fat and its fractions. Food Chem 34:261-271

5. Abu-Lehia IH, Al-Mohiezea IS, El-Behry M (1989) Studies on the production of ice cream from camel milk products. Aust $\mathbf{J}$ Dairy Technol 44:31-34

6. Agrawal RP, Beniwal R, Kochar DK, Tuteja FC, Ghorui SK (2005) Camel milk as an adjunct to insulin therapy improves long-term glycemic control and reduction in doses of insulin in patients with type-1 diabetes A 1 year randomized controlled trial. Diabetes Res Clin Pract 68:176-177

7. Agrawal RP, Saran S, Sharma P, Gupta R, Kochar DK, Sahani MS (2007) Effect of camel milk on residual $\beta$-cell function in recent onset type 1 diabetes. Diabetes Res Clin Pract 77:494-495

8. Ahmed AS, Abdalbagi NH, Mustafa HA, Idris AAA, Eltayb AMA, Ismail R (2011) The role of camel milk in the reactivation of liver damaged by Sudanese liquor (Aragi). J Public Health 6:157-163

9. Akhmetsadykova S, Konuspayeva S, Loiseau G, Baubekova A, Kanayat S, Akhmetsadykov N, Faye B (2012) Protection against lead contamination by strains of Lactic Acid Bacteria (LAB) from fermented camel milk. In: Proceedings of the 3rd conference of the international society of camelid research and development, Muscat, Sultanate of Oman, pp 420-22 https://www.academia.edu/4489898/Farmers_Attitude_Towards _Interventions_Regarding_Camel_Calf_Health_Care: Date of Access: 24 July 2015

10. Alhaj OA, Al Kanhal HA (2010) Compositional, technological and nutritional aspects of dromedary camel milk. Int Dairy $\mathbf{J}$ 20:811-821

11. Alhaj OA, Kanekanian A, Peters A (2007) Investigation on whey proteins profile of commercially available milk-based probiotics health drinks using fast protein liquid chromatography (FPLC). Br Food J 109:469-480

12. Al-Juboori AT, Mohammed M, Rashid J, Kurian J, El Refaey S (2013) Nutritional and medicinal value of camel (Camelus dromedarius) milk. In: Brebbia CA (ed) Food and environment II: the quest for a sustainable future. WIT Press, Ashurst, pp 221-232

13. Attia H, Kherouatou N (2001) Dromedary milk lactic acid fermentation: microbiological and rheological characteristics. J Ind Microbiol Biotechnol 26:263-270

14. Bai Y, Zhao D (2015) The acid-base buffering properties of Alxa Bactrian camel milk. Small Rumin Res 123:287-292

15. Beg OU, Bahr-Lindström HV, Zaidi ZH, Jornvall H (1986) A camel milk whey protein rich in half cystine. Primary structure, assessment of variations, internal repeat patterns, and relationships with neurophysin and other active polypeptides. Eur $\mathbf{J}$ Biochem 159:195-201

16. Benkerroum N (2008) Antimicrobial activity of lysozyme with special relevance to milk. Afr J Biotechnol 7:4856-4867

17. Buonopane GJ, Kilara A, Smith JS, McCarthy RD (1992) Effect of skim milk supplementation on blood cholesterol concentration, blood pressure, and triglycerides in a free-living human population. J Am Coll Nutr 11:56-67

18. Chuvakova ZK, Beisembayeva RU, Puzyrevskaya OM, Saubenouva MG, Shamenova MG, Glebova TI, Popova EI, Baizhomartova MM, Baimenov EK (2000) Chemical composition, microbial control and antiviral properties of freshly made and conserved Shubat "Bota". In: Park YW (ed) Bioactive components in milk and dairy products. Wiley, Hoboken, 2009, pp $171-172$

19. DAHDF (2014) Livestock census of India 19th edition. All India report, published by: Ministry of agriculture department of animal husbandry, dairying and fisheries, KrishiBhawan, New Delhi,

PP-26. http://dahd.nic.in/dahd/WriteReadData/Livestock.pdf

20. Davies DT, Law AJR (1980) Content and composition of protein in creamy milk in South-West Scotland. J Dairy Res 47:83-90

21. Dilanyan SH (1959). Utilisation of mares', ewes', camels and yaks' milk in the USSR Report Int. Comm. Dairying in warm countries. Brussels, Belgium: International Dairy Federation http://whqlibdoc.who\%20int/monograph/ WHO_MONO_48_p681.pdf

22. Duhaiman Ali S (1988) Purification of camel milk lysozyme and its lytic effect on Escherichia coli and Micrococcus lysodeikticus. Comp Biochem Physiol Part B 91(4):793-796

23. El Harrak M, Faye B, Bengoumi M (2011) Main pathologies of camels, breeding of camels, constraints, benefits and perspectives. (http://www.oie.int/doc/ged/D12812.PDF Date of Access 2 Oct 2016

24. El Miniawy HMF, Ahemad KA, Tony MA, Mansour SA, Khattab MMS (2014) Camel milk inhibits murine hepatic carcinogenesis initiated by diethylnitrosamine and promoted by phenobarbitone. Indian J Vet Sci Med 2:137-141

25. El-Agamy EI (2000) Effect of heat treatment on camel milk proteins with respect to antimicrobial factors: a comparison with cows and buffalo milk proteins. Food Chem 68:227-232

26. El-Agamy EI, Ruppanner R, Ismail A, Champagne CP, Assaf R (1992) Antibacterial and antiviral activity of camel milk protective proteins. J Dairy Res 59:169-175

27. El-Agamy EI, Abou-Shloue ZI, Abdel-Kader YI (1998) Gel electrophoresis of proteins, physicochemical characterization and vitamin $\mathrm{C}$ content of milk of different species. Alex J Agric Res 43:57-70

28. El-Agamy EI, Nawar M, Shamsia SM, Awad S, Haenlein GFW (2009) Are camel milk proteins convenient to the nutrition of cow milk allergic children. Small Rumin Res 82:1-6

29. Elayan AA, SuliemanA E, Saleh FA (2008) The hypo-cholesterolemic effect of Gariss and Gariss containing Bifidobacteria in rats fed on a cholesterol-enriched diet. Asian J Biochem $3: 43-47$

30. El-Fakharany EM, Tabil A, El-Wahab AA, Haroun BM, Redwan EM (2008) Potential activity of camel milk amylase and lactoferrin against hepatitis $\mathrm{C}$ virus infectivity in HepG2 and lymhpocytes. Hepat Mon 8(2):101-109

31. El-Rashdy MR, Tabll A (2007) Camel lactoferrin markedly inhibits hepatitis $\mathrm{C}$ virus genotype 4 infection of human peripheral blood leukocytes. J Immunoassay Immunochem 28(3):267-277

32. El-Zubeir IEM, Jabreel MSO (2008) Fresh cheese from camel milk coagu-lated with Cami oc. Int J Dairy Technol 61:90-95

33. FAOSTAT, (2015) Animal Production Yearbook, Food \& Agricultural Organization, Rome, Italy. http://faostat3.fao.org/download/Q/QA/E (Accessed 31 July 2015)

34. Farah Z (1996) Camel milk properties and products. Published: SKAT, Swiss Centre for Developments Cooperation in 
Technology and Management, Vadianstrasse-42, CH—9000 St. Gallen, Switzerland, pp 19-61

35. Farah Z, Rüegg MW (1989) The size distribution of casein micelles in camel milk. Food Microstruct 8:211-216

36. Farah Z, Streiff T, Bachmann MR (1989) Manufacture and characterization of camel milk butter. Milchwissenschaft 44:412-414

37. Farah Z, Mollet M, Younan M, Dahir R (2007) Camel dairy in Somalia: limiting factors and development potential. Livest Sci 110:187-191

38. Faye B, Bengoumi M, Ali Al-Masaud A, Konuspayeva G (2015) Comparative milk and serum cholesterol content in dairy cow and camel. J King Saud Univ Sci 27:168-175

39. Felfoula I, Lopez C, Gaucheron F, Attia H, Ayadi MA (2015) A laboratory investigation of cow and camel whey proteins deposition under different heat treatments. Food Bioprod Process 9(6):256-263

40. Flynn A, Power P (1985) Nutritional aspects of minerals in bovine and human milks. In: Fox PF (ed) Developments in dairy chemistry, Vol 3: lactose and minor constituents. Elsevier, London, pp 183-215

41. Gnan SO, Sheriba AM (1986) Composition of Libyan camel milk. J Dairy Technol 41(1):33-35

42. Habib HM, Ibraham WH, Stock RH, Hassan HM (2013) Camel milk reduces the proliferation of colorectal cancer cells and exerts antioxidant and DNA damage inhibitory activities. Food Chem 141:148-152

43. Haddadin MSY, Gammoh SI, Robinson RK (2008) Seasonal variations in the chemical composition of camel milk in Jordan. J Dairy Res 75:8-12

44. Hamad EM, Abdel-Rahim EA, Romeih EA (2011) Beneficial effect of camel milk on liver and kidneys function in diabetic Sprague-Dawley Rats. Int J Dairy Sci 6:190-197

45. Hashim IB, Khalil AH, Habib H (2008) Quality and acceptability of a set-yoghurt made from camel milk. J Dairy Sci 92:857-862

46. Hassan AH, Hargrass AI, Soryat KA, El-Shabrawy SA (1987) Physico-chemical properties of camel milk during lactation period in Egypt. Egpyt J Food Sci 15(1):1-14

47. HjortafOrnas B (1988) Sustainable subsistence in arid lands: the case of camel rearing. In: HjortafOrnas B (ed) Camels in development. Uppsala, SIAS

48. Hull SJ (2004) Camel's milk to treat diabetes. Nature 363:446-448

49. Inayat S, Arain MA, Khaskheli M, Malik AH (2003) Study of the effect of processing on the chemical quality of soft unripened cheese made from camel milk. Pak J Nutr 2:102-105

50. Jang A, Lee M (2005) Purification and identification of angiotensin converting enzyme inhibitory peptides from beef hydrolysates. Meat Sci 69:653-661

51. Jauregui-Adell J (1975) Heat stability and reactivation of mare milk lysozyme. J Dairy Sci 58(6):835-838

52. Jaydeep Y, Bhavbhuti M, Mehta Wadhwani KN, Darji VB, Aparnathi KD (2015) Evaluation and comparison of camel milk with cow milk and buffalo milk for gross composition. J Camel Pract Res 21(2):259-265

53. Kappeler S (1998) Compositional and structural analysis of camel milk proteins with emphasis on protective proteins. Ph.D. Diss. ETH No. 12947, Zurich, p 12

54. Kappeler S, Farah Z, Puhan Z (1998) Sequence analysis of Camelus dromedarius milk caseins. J Dairy Res 65:209-222

55. Kappeler S, Farah Z, Puhan Z (2003) 5'-Flanking regions of camel milk genes are highly similar to homologue regions of other species and can be divided into two distinct groups. J Dairy Sci 86:498-508
56. Kappeler S, Heuberger C, Farah Z, Puhan Z (2004) Expression of the peptidoglycan recognition protein, PGRP, in the lactating mammary gland. J Dairy Sci 87:2660-2668

57. Khalil IE, Muhammad HA, Hana AA, Inteaz A, Taha R (2011) Comparison and characterization of fat and protein composition for camel milk from eight Jordanian locations. Food Chem 127:282-289

58. Khaskheli M, Arain MA, Chaudhry S, Soomro AH, Qureshi TA (2005) Physico-chemical quality of camel milk. J Agric Soc Sci 2:164-166

59. Konuspayeva G, Faye B, Loiseau G, Levieux D (2007) Lactoferrin and immunoglobulin contents in camel's milk (Camelus bactrianus, Camelus dromedarius, and hybrids) from Kazakhstan. J Dairy Sci 90:38-46

60. Konuspayeva G, Faye B, Loiseau G (2009) The composition of camel milk: a meta-analysis of the literature data. J Food Compos Anal 22:95-101

61. Korhonen H (1977) Antimicrobial factors in bovine colostrum. J Sci Agric Soc Finl 49:434-447

62. Kouniba A, Berrada M, Zahar M, Bengoumi M (2005) Composition and heat stability of Moroccan camel milk. J Camel Pract Res 12:105-110

63. Kumar D, Chatli MK, Raghvendar S, Mehta N, Kumar P (2016) Antioxidant and antimicrobial activity of camel milk casein hydrolysates and its fractions. Small Rumin Res 139:20-25

64. Kumar D, Chatli MK, Raghvendar S, Mehta N, Kumar P (2016) Effects of incorporation of camel milk casein hydrolysate on quality, oxidative and microbial stability of goat meat emulsion during refrigerated $\left(4 \pm 1{ }^{\circ} \mathrm{C}\right)$ storage. Small Rumin Res 144:149-157

65. Kumar D, Chatli MK, Raghvendar S, Mehta N, Kumar P (2016) Enzymatic hydrolysis of camel milk casein and its antioxidant properties. Dairy Sci Technol 96:391-404

66. Kumar D, Chatli MK, Raghvendar S, Mehta N, Kumar P (2016) Enzymatic hydrolysis of camel milk proteins and its antioxidant properties. J Camel Pract Res 23(1):33-40

67. Laleye LC, Jobe B, Wasesa AAH (2008) Comparative study on heat stability and functionality of camel and bovine whey proteins. J Dairy Sci 91:4527-4534

68. Li H, Papadopoulos V (1998) Peripheral-type benzodiazepine receptor function in cholesterol transport. Identification of a putative cholesterol recognition/interaction amino acid sequence and consensus pattern. Endocrinology 139:4991-4997

69. Li GH, Le GW, Shi YH, Shrestha S (2004) Angiotensin I-converting enzyme inhibitory peptides derived from food proteins and their physiological and pharmacological effects. Nutr Res 24:469-486

70. Mal G, Pathak KML (2010) Camel milk and milk products. SMVS Dairy year book, Published by ServaManavVikasSamiti,3/82, Sector-5, Rajendra Nagar, Ghaziabad, Uttar Pradesh, India-01005, pp 97-103

71. Mal G, SuchitraSena D, Jain VK, Sahani MS (2006) Therapeutic value of camel milk as a nutritional supplement for multiple drug resistant (MDR) tuberculosis patients. Isr J Vet Med 61(3-4):88-94

72. Mal G, SuchitraSena D, Sahani MS (2007) Changes in chemical and macro-minerals content of dromedary milk during lactation. J Camel Pract Res 14(2):195-197

73. Mal G, Sena DS, Kishore N, Patil NV (2012) Comparative account of whey proteins in camel and cow milk. Indian Vet $\mathrm{J}$ 89(6): 116-117

74. Mann JI (2002) Diet and risk of coronary heart disease and type 2 diabetes. The Lancet 360:783-789

75. Mehaia MA (2006) Manufacture of fresh soft white cheese (Domiati-type) from dromedary camels milk using ultrafiltration process. J Food Technol 4:206-212 
76. Mehaia MA, Al-Kahnal MA (1989) Studies on camel and goat milk proteins. Nutr Rep Int 39(2):351-357

77. Mehaia MA, Hablas MA, Abdel-Rahman KM, El-Mougy SA (1995) Milk composition of Majaheim, Wadah and Hamra camels in Saudi Arabia. Food Chem 52:115-122

78. Mehta SC, Pathak KML, Bhardwaj B, Arora S, Bhatnagar CS (2009) Camel dairying: an Indian perspective. Indian J Anim Sci 79(4):454-456

79. Mehta SC, Bissa UK, Patil NV, Pathak KML (2011) Importance of camel milk and production potential of dromedary breeds. Indian J Anim Sci 81(11):1173-1177

80. Minervini F, Algaron F, Rizzello CG, Fox PF, Monnet V, Gobbetti M (2003) Angiotensin I-converting-enzyme inhibitory and antibacterial peptides from Lactobacillushelveticus PR4 proteinase hydrolyzed caseins of milk from six species. Appl Environ Microbiol 69:5297-5305

81. Moslehishad M, Ehsani MR, Salami M, Mirdamadi S, Ezzatpanah H, Moosavi-Movahed AN, Naslaji AA (2013) The comparative assessment of ACE-inhibitory and antioxidant activities of peptide fractions obtained from fermented camel and bovine milk by Lactobacillus rhamnosus PTCC 1637. Int Dairy J 29:82-87

82. Nanda DK, Tomar SK, Singh R, Mal G, Singh P, Arora DK, Joshi BK, Chaudhary R, Kumar D (2011) Phenotypic and genotypic characterisation of Lactobacilli isolated from camel cheese produced in India. Int J Dairy Technol 64(3):437-443

83. Narmuratova M, Konuspayeva G, Loiseau G, Serikbaeva A, Natalie B, Didier M, Faye B (2006) Fatty acids composition of dromedary and Bactrian camel milk in Kazakhstan. J Camel Pract Res 13(1):45-50

84. Ochoa TJ, Cleary TG (2009) Effect of lactoferrin on enteric pathogens. Biochimie 91:30-34

85. Omer RH, Eltinay AH (2009) Changes in chemical composition of camel's raw milk during storage. Pak J Nutr 8:607-610

86. Quan S, Tsuda H, Miyamoto T (2008) Angiotensin I-converting enzyme inhibitory peptides in skim milk fermented with Lactobacillushelveticus 130B4 from camel milk in Inner Mongolia, China. J Sci Food Agric 88:2688-2692

87. Raghvendar S, Sahani MS (2005) Value added camel milk products. National seminar on value added dairy products, 22-25th december: souvenir published by National Dairy Research Institute, Karnal and Dairy Technology Society of India,

$$
\mathrm{p}
$$
http://www.dairysociety.org/pdf/Souvenir_Seminar.pdf

88. Raghvendar S, Tandon SN, Arora S, Sahani MS (2001) Milk enzymes in different breeds of Indian camel. Int J Anim Sci 16(1):85-87

89. Raghvendar S, Sahani MS, Shukla S (2004) Preparation of camel milk products and their utilization. Technical Bulletin, Publisher National Research Center on Camel, Bikaner, India, pp 1-6 http://www.nrccamel.res.in/downloads/ Preperation_of_camel_milk_Products_and_their_utilization.pdf

90. Raghvendar S, Shukla S, Sahani MS (2004) Chemical and physico-chemical properties of camel milk at different stages of lactation. Saving the camel and peoples' livelihoods. In: Proceedings of an international conference held on 23-25 November 2004 in Sadri. LokhitPashu-PalakSansthan, Sadri, Rajasthan, India, $\quad \mathrm{p} \quad 37$ www.pastoralpeoples.org/docs/camel_conf_proc.pdf

91. Raghvendar S, Shukla S, Sahani MS (2004) Prospects for adding value to camel milk in India. In: International conference on saving the camel and peoples' livelihoods: proceedings of an international conference held on 23-25 November 2004 in Sadri. LokhitPashu-PalakSansthan, Sadri, Rajasthan, India, p 38 www.pastoralpeoples.org/docs/camel_conf_proc.pdf
92. Raghvendar S, Ghorui SK, Sahani MS (2006) Camel milk: properties and processing potential. In: Sahani MS (ed) The Indian camel. Publisher National Research Center on Camel, Bikaner, pp 59-73

93. Raghvendar S, Sahani MS, Tuteja FC, Aminnudeen, Ghorui SK (2006) Camel milk Skin cream. Technical Bulletin, Publisher National Research Center on Camel, Bikaner, India, pp 9-14 http://www.nrccamel.res.in/downloads/

CAmel_Milk_Suns_Creame.pdf

94. Rahman MS, Al-Hakmani H, Ahmed Al-Alawi A, Al-Marhubi I (2012) Thermal characteristics of freezedried camel milk and its major components. Thermochim Acta 549:116-123

95. Ramdaoui A, Obad I (1998) Caractérisationphysico-chimiqueetmicrobiologique du lait de dromadaire, et étude de sastabilitéthermique. Mémoire de 3cycle présenté pour obtenir le grade d'Ingénieurd'Etaten Industries Agricolesetali-mentaires. Nancy, France: ENSAIA

96. Rao DR, Chawan CB, Pulusani SR (1981) Influence of milk and thermophilus milk on plasma cholesterol levels and hepatic cholesterogenesis in rates. J Food Sci 46:1339-1341

97. Sahani MS, Nagpal AK, Rai AK, Khanna ND (1996) Milk production in Bikaneri camels managed under farm conditions. Indian J Anim Sci 66:415-417

98. Sahani MS, Rathinasabapathy M, Mal G (1998) Milking technique and other factors affecting milk production potential in different breeds of camel under farm conditions. Indian J Anim Sci 68:254-256

99. Sahani MS, Agrawal RP, Tuteja FC, Ghorui SK, Aminudeen A, Raghvendar S, Sena D (2005) Hypoglycemic activity of camel milk in straptozotocin induced hyperglycemia in rats. Indian $\mathrm{J}$ Anim Sci 75:1436-1437

100. Salami M, Yousefi R, Ehsani MR, Razavi SH, Chobert JM, Haertle T (2009) Enzymatic digestion and antioxidant activity of the native and molten globule states of camel a-lactalbumin: possible significance for use in infant formula. Int Dairy $\mathrm{J}$ 19:518-523

101. Salami M, Moosavi-MovahediAA Moosavi-Movahedi F, Ehsani MR, Yousefi R, Farhadi F (2011) Biological activity of camel milk casein following enzymatic digestion. J Dairy Res 78:471-478

102. Sboui A, Khorchani T, Djegham M, Agrebi A, Elhatmi H, Belhadj O (2010) Anti-diabetic effect of camel milk in allaxoninduced diabetic dogs: a dose-response experiment. J Anim Physiol Anim Nutr 94:540-546

103. Schrezenmeir J, Jagla A (2000) Milk and diabetes. J Am Coll Nutr 19:176-190

104. Shabo Y, Yagil R (2005) Etiology of autism and camel milk as therapy. Int J Disabil Hum Dev 4:67-70

105. Shabo Y, Barzel R, Margoulis M, Yagil R (2005) Camel milk for food allergies in children. Immunology and allergies. Israel Med Assoc J 7:1-3

106. Sharmanov TS, Kadyrova RD (1978) Changes in the indicators of radioactive isotope studies of the liver of patients with chronic hepatitis during treatment with whole camels' milk and mares' milk. Voprosy Pytaniya 1:9-13

107. Shori AB (2015) Camel milk as a potential therapy for controlling diabetes and its complications: a review of in vivo studies. J Food Drug Anal 30:1-10

108. Shuiep ES, El Zubeir IEM, El Owni OAO, Musa HH (2008) Influence of season and management on composition of raw camel (Camelus dromedarius) milk in Khartoum state, Sudan. Trop Subtrop Agroecosystems 8:101-106

109. Sibtain AS, Muhammad Y, Muhammad QB, Muhammad KK, Ghulam M, Li-Guo Y, Muhammad T (2012) Factors affecting yield and composition of camel milk kept under desert 
conditions of central Punjab, Pakistan 12. Trop Anim Health Prod 44:1403-1410

110. Smits MG, Huppertz T, Alting AC, Kiers J (2011) Composition, constituents and properties of dutch camel milk. J Camel Pract Res 18(1):1-6

111. Stahl T, Sallman HI, Duehlmeier R, Wernery U (2006) Selected vitamins and fatty acid patterns in dromedary milk and colostrum. J Camel Pract Res 13(1):53-57

112. Sunita S, Rajput YS, Sharma R (2014) Comparative fat digestibility of goat, camel, cow and buffalo milk. Int Dairy J 35:153-156

113. Taha NM, Keilwein G (1989) Studies on the nitrogen distribution and content of peptide bounds and free amino acids in camel milk, buffalo and ass milk. Milchwissenschaft 44:633-636

114. Wang SY, Liang JP, Shao WJ, Wen H (2011) Mineral, vitamin and fatty acid contents in the camel milk of dromedaries in the anxigansu china. J Camel Pract Res 18(2):273-276

115. Wang N, Wang KY, Li G, Guo W, Liu D (2015) Expression and characterization camel chymosin in Pichia pastoris. Protein Expr Purif 111:75-81

116. Wangoh J (1997) Chemical and technological properties of camel (Camelus dromedarius) milk. Diss ETH Nr 12295, Swiss Federal Institute of Technology, Zurich, Switzerland
117. Wangoh J, Farah Z, Puhan Z (1998) Composition of milk from three camel (Camelus dromedarius) breeds in Kenya during lactation. Milchwissenschaft 53:136-139

118. Yagil R (1982) Camels and camel milk. Animal production and health report. Rome, Italy: FAO, pp 8-26 http://afghanag.ucdavis.edu/c_livestock/camels/ Man_Live_Camel_Milk_FAO.pdf

119. Yagil R (2000) Lactation in the desert camel (Camelus dromedarius). In: Gahlot TK (ed) Selected topics in camelids. The Camelid Publishers, Bikaner, pp 61-73

120. Yagil R (2013) Camel milk and its unique anti-diarrheal properties. Israel Med Assoc J 15:35-36

121. Yagil R, Etzion Z (1980) Effect of drought condition on the quality of camel milk. J Dairy Res 47:159-166

122. Yoshida S, Ye-Xiuyun (1991) Isolation of lactoperoxidase and lactoferrins from bovine milk acid whey by carboxymethyl cation exchange chromatography. J Dairy Sci 74(5):1439-1444

123. Zhang H, Yao J, Zhao D, Liu H, Guo M (2005) Changes in chemical composition of Alxabactrian camel milk during lactation. J Dairy Sci 88(10):3402-3410

124. Zhao D, Bai Y, Niu Y (2015) Composition, characteristics of Chinese Bacterian camel milk. Small Rumin Res 127: 58-67 J Dairy Sci 88(10): 3402-3410 